\title{
ВИКЛАДАННЯ ДИСЦИПЛІНИ “ОСНОВИ ПСИХОЛОГІЇ”: СУЧАСНИЙ СТАН ТА ПЕРСПЕКТИВИ
}

\section{D. Spirina, A. V. Shornikov, E. S. Fawzy \\ Dnipropetrovsk Medical Academy, Dnipro \\ TEACHING A DISCIPLINE OF BASES OF PSYCHOLOGY: THE CURRENT STATE AND PERSPECTIVES}

\begin{abstract}
Мета роботи - оцінка потреби студентів у викладанні дисципліни “Основи психологіі” та пошук шляхів відновлення викладання цієї дисципліни в розрізі стратегії розвитку медичної освіти в Україні.

Основна частина. Медична освіта України має готувати фахівців високого рівня заради забезпечення громадян якісною медичною допомогою. Перелік навчальних дисциплін і, відповідно, компетентностей затверджується стандартами медичної освіти. Діючий наразі стандарт перевів дисципліну “Основи психології” для студентів у галузі знань 22 “Охорона здоров’я”, за фахом 222 “Медицина”, 221 “Стоматологія” з обов’язкової до дисциплін за вибором. У статті наводяться дані опитування 482 студентів III та IV курсів, які навчаються за спеціальністю “Лікувальна справа”, зокрема 113 студентів - громадян інших країн, які вивчали цю дисципліну ще за попереднім стандартом. Переважна більшість опитаних (98,5 \%) вважає, що у вищому медичному навчальному закладі потрібно вивчати дисципліну “Основи психології”, а 81,3 \% опитаних стверджують, що ця дисципліна має бути обов'язковою до вивчення.

Висновок. За результатами дослідження зроблено висновок про необхідність вчасного перегляду стандартів вищої освіти, зокрема з урахуванням думок студентів, та запропоновано повернути дисципліну “Основи психології” до обов’язкових дисциплін.
\end{abstract}

Ключові слова: студенти; основи психології; стандарти освіти; стратегія реформ.

The aim of the work - assessment of the students' needs in the discipline of Bases of Psychology and the search for ways to restore the teaching of this discipline in the context of the strategy of medical education development in Ukraine.

The main body. Ukraine's medical education has to prepare high-level specialists to provide quality medical care. The list of educational disciplines and competencies is approved by the standards of medical education. The current standard had moved the discipline of Basics of Psychology to students in the field of knowledge Health 22, in specialty of Medicine 222, Stomatology 221 from compulsory disciplines to disciplines that should be selected. The article provides data on the survey of 482 students of the III and IV courses trained in the specialty of Medicine, in particular 113 students - citizens of other countries who studied this discipline according to the previous standard. Most of the polled students (98.5\%) believe that in the higher medical school needs to study the discipline of Basics of Psychology, and $81.3 \%$ of the respondents claim that this discipline should be mandatory.

Conclusion. The study concluded that there was a need for a timely revision of the standards of higher education, in particular taking into account the views of students, and proposed to return the discipline of Basics of Psychology to compulsory disciplines.

Key words: students; basics of psychology; education standards; strategy of reforms.

Вступ. Медична освіта, розвиваючись паралельно із суспільством, постійно потребує оновлення та вдосконалення. Регулярно відбувається оновлення типових та робочих програм із дисциплін. Проте перелік дисциплін залишається сталим на багато років: стандарти вищої освіти, освітньо-кваліфікаційні програми та характеристики затверджуються на десятиріччя, останнє затвердження відбулось у 2016 р. Заступник міністра охорони здоров’я О.В. Лінчевський зі співавторами зазначають, що від кількісних показників роботи медичних універ-

(С I. Д. Спіріна, А. В. Шорніков, Є. С. Фаузі ситетів треба робити акценти на питаннях якості підготовки лікарів та провізорів [1]. Ці ідеї знайшли відображення у стратегії розвитку медичної освіти в Україні, в якій основний акцент робиться на забезпеченні громадян якісною медичною допомогою через високий рівень підготовки медичних фахівців [2]. Ця стратегія передбачає оновлення змісту освіти 3 обов'язковою розробкою нових стандартів освіти.

Відповідно до Концепції розвитку охорони психічного здоров'я в Україні на період до 2030 р., схваленої розпорядженням Кабінету Міністрів 
України від 27 грудня 2017 р. № 1018-р, серед основних компонентів проблеми у сфері охорони психічного здоров'я в Україні виділяють слабку обізнаність щодо психічного здоров'я у суспільстві, недостатність системи формування та підтримки професійних компетентностей серед фахівців у сфері психічного здоров'я та інших суміжних професій [3]. Таким чином, передбачається, що лікарі загальної практики та інші фахівці будуть забезпечувати впровадження програм профілактики проблем психічного здоров'я та забезпечать доступність допомоги щодо психічного здоров'я на рівні територіальних громад.

Викладання дисципліни “Основи психології” $\epsilon$ основоположним у системі наук про психіку і поведінку людини, таких, як медична психологія, психологія спілкування, психіатрія і наркологія, психотерапія. I якщо не всі випускники медичних вузів стають психіатрами, то всім необхідні знання психології хворої людини, розуміння проблем, з якими він стикається, вміння уникати і вирішувати конфлікти.

Зазначимо, що дисципліна “Основи психології” формує, крім загальних компетенцій, такі важливі професійні компетенції, як навички опитування та клінічного обстеження пацієнта. Також завдяки цій дисципліні студенти опановують і покращують навички комунікації як специфічного виду діяльності, вивчають індивідуально-психологічні особливості особистості пацієнтів.

Як неможливо вивчати патоморфологію без знання анатомії і гістології, так і вивчення медичної психології та психіатрії неможливе без знань основ психології. Особливо це актуально в підготовці іноземних студентів. Адже найчастіше теми для самостійного вивчення вони обходять стороною, а рівень їх мовної підготовки може бути недостатнім для засвоєння в короткі терміни відомостей щодо психічних процесів, психічних явищ, психічних станів та їх властивостей. Висновки, які наведені в Концепції розвитку охорони психічного здоров'я в Україні, грунтуються на даних попередніх років, коли дисципліна “Основи психології” була обов’язковою до навчання. Важко уявити, до яких же висновків дійшли автори, оцінюючи сучасний стан медичної освіти, з вибірковістю дисципліни, яка формує фундамент для реалізації заходів щодо забезпечення психічного здоров’я населення.

У примірному навчальному плані підготовки фахівців другого (магістерського) рівня вищої освіти галузі знань 22 “Охорона здоров’я” у вищих навчальних закладах Міністерства охорони здоров’я України за спеціальністю 222 “Медицина” кваліфікації освітньої “Магістр медицини”, кваліфікації професійної “Лікар”, затвердженому листом МО3 України № 08.01-30/19087 від 25.07.2016 р., навчальна дисципліна “Основи психології” пропонується у блоці вибіркових дисциплін для студентів I курсу.

Оскільки, згідно з розділом 2 примірного положення про опорну кафедру, одним із завдань кафедри є розробка пропозицій та рекомендацій щодо вдосконалення організації та методики підвищення якості підготовки студентів, кафедра психіатрії, загальної та медичної психології Державного закладу “Дніпропетровська медична академія Міністерства охорони здоров'я України”, як опорна кафедра 3 дисципліни “Медична психологія” для студентів за спеціальностями "Медицина" та "Стоматологія”, на підставі власних досліджень пропонує дискусію щодо необхідності відновлення викладання дисципліни “Основи психології” як обов’язкової дисципліни.

Мета роботи - оцінка потреби студентів у викладанні дисципліни “Основи психології” та пошук шляхів відновлення викладання цієї дисципліни в розрізі стратегії розвитку медичної освіти в Україні.

Основна частина. Ми провели добровільне анкетування студентів III-IV курсів, які проходили навчання на кафедрі психіатрії, загальної та медичної психології у весняному семестрі 2017-2018 н. р. за дисциплінами “Медична психологія” та “Психіатрія. Наркологія”, зокрема іноземних, щодо необхідності викладання дисципліни “Основи психології” на I курсі. В опитуванні взяли участь 482 студенти III та IV курсів, які навчаються за спеціальністю “Лікувальна справа”, зокрема 113 студентів - громадян інших країн. Для опитування ми використала анкету з такими питаннями:

1. Чи потрібно Вам вивчати дисципліну “Основи психології”?

2. Чи повинна дисципліна “Основи психології” бути обов’язковою до навчання?

Варіанти відповідей передбачали вибір між двома твердженнями: “так” або “ні”.

Для подальшого опрацювання обрано 479 анкет: 304 анкети студентів III курсу та 175 анкет студентів IV курсу, 3 анкети не оброблювалися, тому що студенти не відповіли на поставлені питання.

Отримано такі результати. 
3 питання “Чи потрібно Вам вивчати дисципліну “Основи психології”?

\begin{tabular}{|l|l|c|c|c|c|c|c|}
\hline \multicolumn{2}{|c|}{ Питання } & $\begin{array}{c}3 \\
\text { курс }\end{array}$ & $\begin{array}{c}\% \\
3 \text { курс }\end{array}$ & $\begin{array}{c}4 \\
\text { курс }\end{array}$ & $\begin{array}{c}\% \\
4\end{array}$ & $\begin{array}{c}\text { Зага- } \\
\text { лом }\end{array}$ & $\%$ \\
\hline $\begin{array}{l}\text { Потрібно } \\
\text { вивчати }\end{array}$ & так & 299 & 98,4 & 173 & 98,9 & 472 & 98,5 \\
\cline { 2 - 9 } & нi & 5 & 1,6 & 2 & 1,1 & 7 & 1,5 \\
\hline Разом & 304 & 100 & 175 & 100 & 479 & 100 \\
\hline
\end{tabular}

3 питання “Чи повинна дисципліна “Основи психології” бути обов’язковою до навчання?”

\begin{tabular}{|c|c|c|c|c|c|c|c|}
\hline \multicolumn{2}{|l|}{ Питання } & $\begin{array}{c}3 \\
\text { курс }\end{array}$ & $\begin{array}{c}\% \\
3 \text { курс }\end{array}$ & $\begin{array}{c}4 \\
\text { курс }\end{array}$ & $\begin{array}{c}\% \\
4 \text { курс }\end{array}$ & $\begin{array}{c}\text { Зага- } \\
\text { лом }\end{array}$ & $\%$ \\
\hline \multirow{2}{*}{$\begin{array}{l}\text { Обов’язкова } \\
\text { дисципліна }\end{array}$} & так & 223 & 73,4 & 159 & 90,8 & 382 & 81,3 \\
\hline & Hi & 81 & 26,6 & 16 & 9,1 & 97 & 18,7 \\
\hline \multicolumn{2}{|l|}{ Разом } & 304 & 100 & 175 & 100 & 479 & 100 \\
\hline
\end{tabular}

Таким чином, переважна більшість студентів (98,5 \%) як третього, так і четвертого року навчання вважає, що їм необхідне вивчення дисципліни “Основипсихології”. Стосовно обов’язковості вивчення цієї дисципліни вже менший відсоток студентів вважає, що ця дисципліна мала би бути обов'язковою, а не у переліку предметів варіативної компоненти програми. Зауважимо, що на четвертому курсі більшість студентів вважає, що дисципліна “Основи психології” має бути обов’язковою для вивчення, оскільки стикаючись із вивченням психіатрії та маючи більший досвід навчання на клінічних кафедрах, вони розуміють актуальність потреби в знаннях із психології, зокрема для успішного спілкування з пацієнтами.

\section{Список літератури}

1. Шляхи реформування системи вищої медичної освіти в Україні в сучасних умовах / О. В. Лінчевський, В. М. Черненко, Ю. С. П’ятницький, І. Є. Булах // Медична освіта. - 2017. - № 3. - С. 6-9.

2. Стратегія розвитку медичної освіти в Україні [Електронний ресурс] // МОЗ України. - 2018. - Режим доступу до ресурсу : http://moz.gov.ua/uploads/1/7066-14_08_ strategia.pdf.

\section{References}

1. Linchevskyi, O.V., Chernenko, V.M., Piatnytskyi, Yu.S., \& Bulakh, I.Ye. (2017). Shliakhy reformuvannia systemy vyshchoi medychnoi osvity v Ukraini v suchasnykh umovakh [The ways of higher medical education system reforming in Ukraine in the modern context]. Medychna osvita - Medical Education, (3), 6-9. DOI 10.11603/ me.2414-5998.2017.3.7753 [in Ukrainian].

2. Stratehiia rozvytku medychnoi osvity v Ukraini [Strategy for the development of medical education in Ukraine]. Retrieved from: http://moz.gov.ua/uploads/1/7066-14_08_ strategia.pdf [in Ukrainian].

Електронна адреса для листування: shornikov@ukr.net
Висновки. Відмічено, що в умовах теперішнього розвитку громадянського суспільства студенти як учасники освітнього процесу більш активно вносять свої пропозиції щодо подальшого покращення якості підготовки майбутніх лікарів [4]. Тому ми пропонуємо дослухатися до думки студентів, особливо стосовно переліку основних та варіативних дисциплін. Особливо це актуально для студентів I курсу, які ще не повною мірою можуть оцінити, які дисципліни необхідно вивчати задля подалышого успіху. Вже на третьому та, особливо, на четвертому курсі майбутні лікарі починають розуміти, що потрібно вивчати не лише хвороби та методи їх діагностики та лікування, а й психіку людини, особливо хворої. Саме дисципліна “Основи психологіӥ” формує необхідну понятійну базу для якісного опановування дисциплін “Медична психологія” та “Психіатрія. Наркологія” для формування необхідних компетентностей майбутніх лікарів. Виходячи з положень Стратегї розвитку медичної освіти в Україні для забезпечення високої якості української медичної освіти, ми пропонуємо не просто повернути дисципліну “Основи психології” з предметів для вибору до обов’язкових предметів, ми пропонуємо усім разом розробити механізми швидкого й ефективного перегляду навчальних планів, зокрема і за ініціативи та участі студентів. Вся діяльність системи медичної освіти має бути спрямована на покращення якості навчання студентів і сприяння досягненню найвищих успіхів у професійній діяльності.

3. Концепція розвитку охорони психічного здоров'я в Україні на період до 2030 року // Український вісник психоневрології. - 2018. - Т. 26, № 1. - С. 127-130.

4. Шляхи підвищення якості навчання на підставі моніторингу анкетування випускників академії / Г. В. Дзяк, Т. О. Перцева, С. В. Захаров, Г. В. Горбунова // Медична освіта. - 2015. - № 2. - С. 64-66.

3. Kontseptsiia rozvytku okhorony psykhichnoho zdorovia v Ukraini na period do 2030 roku [The concept of the development of mental health in Ukraine for the period up to 2030]. Ukrainskyi visnyk psykhonevrolohii - Ukrainian Journal of Psychoneurology, 26, (1), 127-130 [in Ukrainian].

4. Dziak, H.V., Pertseva, T.O., Zakharov, S.V., \& Horbunova, H.V. (2015). Shliakhy pidvyshchennia yakosti navchannia na pidstavi monitorynhu anketuvannia vypusknykiv akademii [Quality improving ways of education based on monitoring of academy graduates' survey]. Medychna osvita - Medical Education, (2), 64-66. Retrieved from: https://doi.org/10.11603/me.v0i2.4146 [in Ukrainian].

Отримано 10.10.18 